RESEARCH

SERIES

NUMBER 100

December 2019

\section{TRANSITIONING TO A LOW-CARBON IRISH ECONOMY: AN ANALYSIS OF REGIONAL LABOUR IMPACTS}

KELLY DE BRUIN, MARTINA LAWLESS, EOIN MONAGHAN AND AYKUT MERT YAKUT

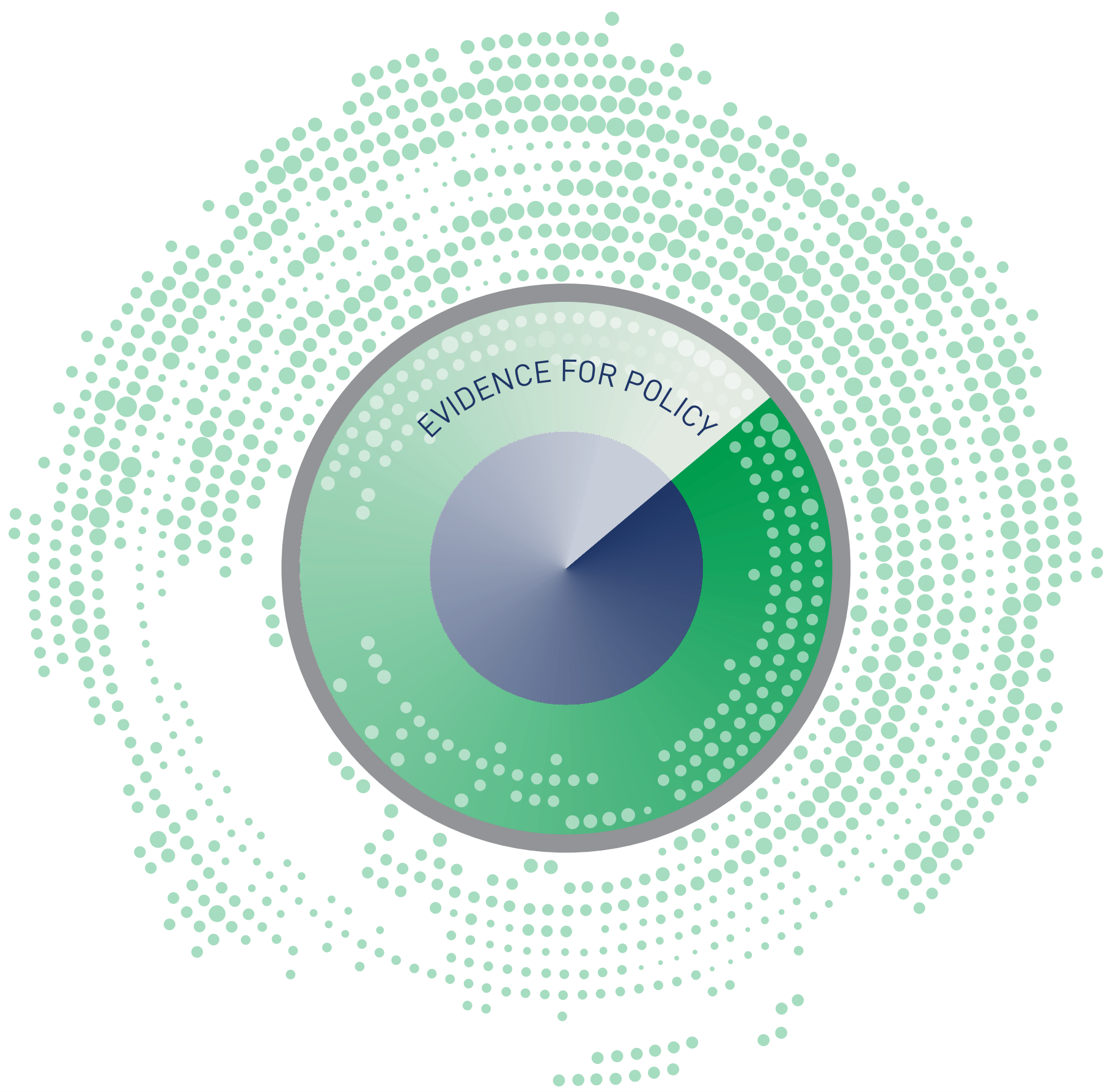




\section{Transitioning to a Low-Carbon Irish Economy: An Analysis of Regional Labour Impacts}

Kelly de Bruin

Martina Lawless

Eoin Monaghan

Aykut Mert Yakut

December 2019

\section{RESEARCH SERIES \\ NUMBER 100}

Available to download from www.esri.ie

() The Economic and Social Research Institute

Whitaker Square, Sir John Rogerson's Quay, Dublin 2

ISBN 978-0-7070-0514-0

DOI https://doi.org/10.26504/rs100

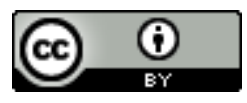

This Open Access work is licensed under a Creative Commons Attribution 4.0 International License (https:// creativecommons.org/licenses/by/4.0/), which permits unrestricted use, distribution, and reproduction in any medium, provided the original work is properly credited. 


\section{ABOUT THE ESRI}

The mission of the Economic and Social Research Institute is to advance evidence-based policymaking that supports economic sustainability and social progress in Ireland. ESRI researchers apply the highest standards of academic excellence to challenges facing policymakers, focusing on 12 areas of critical importance to 21 st century Ireland.

The Institute was founded in 1960 by a group of senior civil servants led by Dr T. K. Whitaker, who identified the need for independent and in-depth research analysis to provide a robust evidence base for policymaking in Ireland.

Since then, the Institute has remained committed to independent research and its work is free of any expressed ideology or political position. The Institute publishes all research reaching the appropriate academic standard, irrespective of its findings or who funds the research.

The quality of its research output is guaranteed by a rigorous peer review process. ESRI researchers are experts in their fields and are committed to producing work that meets the highest academic standards and practices.

The work of the Institute is disseminated widely in books, journal articles and reports. ESRI publications are available to download, free of charge, from its website. Additionally, ESRI staff communicate research findings at regular conferences and seminars.

The ESRI is a company limited by guarantee, answerable to its members and governed by a Council, comprising 14 members who represent a cross-section of ESRI members from academia, civil services, state agencies, businesses and civil society. The Institute receives an annual grant-in-aid from the Department of Public Expenditure and Reform to support the scientific and public interest elements of the Institute's activities; the grant accounted for an average of 30 per cent of the Institute's income over the lifetime of the last Research Strategy. The remaining funding comes from research programmes supported by government departments and agencies, public bodies and competitive research programmes.

Further information is available at www.esri.ie 


\section{THE AUTHORS}

Martina Lawless in an Associate Research Professor at the Economic and Social Research Institute (ESRI). Kelly de Bruin and Aykut Mert Yakut are Research Officers, and Eoin Monaghan is a Research Assistant at the ESRI.

\section{ACKNOWLEDGEMENTS}

The research carried out in this report was funded by the Department of Communications, Climate Action and Environment (DCCAE) and is part of an ongoing modelling project.

This report has been accepted for publication by the Institute, which does not itself take institutional policy positions. The report has been peer reviewed prior to publication. The authors are solely responsible for the content and the views expressed. 


\section{Table of Contents}

1 Introduction $\quad 6$

2 Methods $\quad 7$

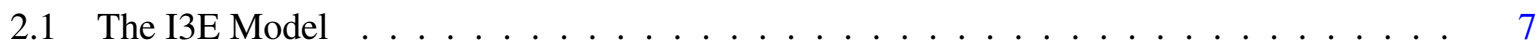

2.2 Regional linking . . . . . . . . . . . . . . . . . . . . . 10

3 Scenario Design and Results $\quad 11$

3.1 Macroeconomic Results . . . . . . . . . . . . . . . . . . . . . . . . . . 12

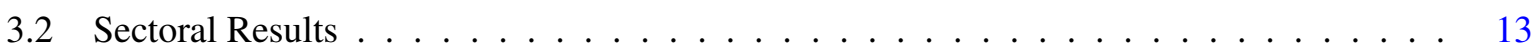

3.3 Regional Analysis . . . . . . . . . . . . . . . . . . . . . . 15

4 Conclusion $\quad 20$

$\begin{array}{ll}\text { References } & 21\end{array}$

Appendix Lists of Sectors, Commodities, and Counties 22 


\section{EXECUTIVE SUMMARY}

\section{Introduction}

Ireland has legally binding emissions reduction targets for 2020 and 2030. To achieve these targets and to become a low-carbon economy, the government uses carbon taxation as one of the primary policy tools. In addition, ceasing of peat and coal, which are the most polluting energy commodities from electricity production, is planned. However, given the concentration of specific production sectors in specific regions, there is a concern that the labour impacts for certain regions/counties will be high, compared to others. This report explores the projected county-level variation in labour demand impacts for 2030, following an increase in the carbon tax and removal of coal and peat in electricity production. More specifically, the electricity production sector will gradually phase out coal and peat from the production process, their usages will be terminated in 2026 and 2029, respectively, and the carbon tax will increase $€ 6$ annually starting from 2020 and reach $€ 80$ in 2029 per tonne $\mathrm{CO}_{2}$-eq. We combine the labour demand output from the Ireland Environment, Energy and Economy (I3E) computable general equilibrium (CGE) model, with regional employment statistics to highlight sectoral and county-level variation. Firstly, we assess the sectoral labour demand impacts, and these sectoral results are then "shared out" to evaluate labour demand impacts for each county.

\section{Main Findings}

- Government-based sectors such as health, education and public administration face positive labour demand impacts owing to an increase in government consumption due to the increased carbon tax.

- Meanwhile, carbon-intensive sectors like mining and transportation stand to face negative labour demand impacts. However, these most-impacted sectors are not amongst the largest in the economy.

- The overall county-level results are positive for most counties, with Sligo, Roscommon, Galway and Tipperary faring the best.

- Dublin and Westmeath face the most negative labour demand impacts, due to their comparatively larger shares of employees in the most-impacted sectors. It must be said, however, that these impacts are relatively small.

- Our results indicate the need to design climate change policy with adequate focus on those sectors and regions which stand to face disproportionate labour impacts. 


\section{Introduction}

Increased recognition of human-induced (anthropogenic) climate change and its impacts on societies has led to global mitigation commitments to reduce greenhouse gas (GHG) emissions. In 2015, the Paris Agreement ${ }^{1}$ was adopted, and to date, it has been ratified by 194 states and the European Union (though the US has begun formal procedures to withdraw from the agreement). As an EU member state, Ireland is committed to a $20 \%$ reduction in its GHG emissions compared to 2005 levels by $2020 .^{2}$ Ireland also faces a renewable energy target of $16 \%$ of final energy use and $10 \%$ of energy use in transportation. These targets are legally binding, and Ireland will face fines should it not meet its targets, though the exact level of these fines is uncertain.

The Irish government has confirmed its commitment to transitioning to a low-carbon economy, in the recently published Irish All of Government Climate Action Plan (Government of Ireland, 2019). Furthermore, the government increased the Irish carbon tax from $€ 20$ to $€ 26$ per tonne of $\mathrm{CO}_{2}$ in Budget 2020, with a view to subsequent annual $€ 6$ increases such that the tax will reach $€ 80$ per tonne by 2030.

A major concern with transitioning to a low-carbon economy is ensuring a fair distribution of the associated costs across businesses and households. A core focus of a just transition relates to jobs and livelihoods. Given the concentration of specific production sectors in specific regions, there is a concern that the labour impacts for certain communities will be high. ${ }^{3}$ The Irish government has emphasised the need for a just transition, meaning that the government is committed to making changes while ensuring that no member of society gets left behind.

Most of the existing literature on environmental taxation is concerned only with national, macro and micro levels, including households' and firms' results. For example, early work from FitzGerald \& McCoy (1992) uses the ESRI's HERMES model to investigate the economic effects of the introduction of a combined carbon/energy tax in Ireland. It finds that unemployment initially increases following the imposition of the tax, but after that decreases as emigration increases. Kato et al. (2013) uses a vector autoregression method to analyse the impacts of a carbon tax increase in the German economy. It finds that employment and output increase whenever the revenue from the tax is used to subsidise less carbonintense industries. IILS (2011) finds, intuitively, that energy tax reforms are most supportive to less carbon-intensive jobs while being less supportive to more carbon-intense industries, though the level of impact in these sectors depends on the level of substitution of factor inputs to more renewable sources.

Only a handful of other papers evaluate regional-level variation. In Belgium, Vandyck \& Regemorter (2014) employs a CGE model to evaluate the regional effects of an increase in oil excise. It finds variable regional macroeconomic effects depending on the energy-intensity of a region's industries, and these effects change with the choice of the revenue recycling scheme. In the case of China, Zhang et al. (2019) finds regional disparity which changes depending on the recycling scheme: when a carbon tax is used to

\footnotetext{
1 https://bit.1y/2Kke05A

2 https://bit.1y/2CH76Di

3 Throughout the text, the terms "region" and "county" are used interchangeably.
} 
cut production tax, the more affluent regions of China are made better off, whereas this case is reversed if the revenue is instead used as a transfer to low-income households. Elsewhere, Ciaschini et al. (2012) also use CGE modelling to analyse regional disparity in Italy, finding positive effects for the North-Centre region, but potentially negative impacts on employment in the South-Islands area. Lastly, Hassett et al. (2009), in contrast, finds that average tax burdens from carbon taxes in the USA have fluctuated, but that by 2003 the variation had subsided.

This report investigates the potential impact of a transition to a low-carbon economy on labour demand across counties in Ireland. We do this by augmenting the labour demand results of our CGE model with county-level employment statistics. The key findings at a sectoral level are that government-based sectors like education, health services and public administration will have positive labour demand impacts, while the mining and transportation sectors will have negative impacts. However, the latter sectors are not amongst the largest in the economy as a whole. At a regional level, we find that the majority of counties see overall positive labour demand impacts, the main exceptions being Dublin and Westmeath, owing to their relatively larger shares of workers in the negatively impacted sectors.

The report is structured as follows. Section 2 outlines the I3E model which underpins this analysis, while also outlining the methodology used to apply county-level analysis to our results. Section 3 presents the results of the paper, beginning firstly with sectoral-level results, before showing how these sectoral results are "shared out" across the country. Section 4 concludes.

\section{Methods}

In this report, we apply the $\mathrm{I} 3 \mathrm{E}$ model to investigate the impacts of climate policy on wage rates and labour demand across production sectors. We then use Central Statistics Office (CSO) data concerning the location of firms in the various production sectors to examine the spread of labour impacts across counties. In this section, we will first introduce the I3E model and then discuss how the I3E results are distributed across regions.

\subsection{The I3E Model}

The I3E model is the first fully dynamic, i.e. intertemporal, CGE model for the Irish economy. Pertinently, each production activity in the model has associated GHG and related output, thereby directly linking the economic and environmental aspects of the economy.

In the following subsections, the economic agents defined in the model and the interactions across these agents are discussed in a non-technical manner. The technical details of the model economy are provided in de Bruin \& Yakut (2019b). The model parameters are calibrated by using an energy social accounting matrix (ESAM). The data sources and the details of the construction process of the ESAM are available in de Bruin \& Yakut (2019a). 
1. Households: The I3E model includes ten representative household groups (RHGs). The RHGs with the abbreviations u1 to u5 are the urban resident households, where u1 (u5) represents the poorest (richest) RHG. Similarly, the RHGs with the abbreviations r1 to r5 are the rural resident households, and r1 (r5) represents the poorest (richest) RHG. The RHGs are constructed by using the Household Budget Survey (HBS) of 2015-2016. Each household in the survey is uniquely assigned to a RHG; household-level values of all income items and private consumption expenditures by commodities are then summed to generate the RHG aggregates. In this way, the RHGs defined in the I3E model have distinct compositions of disposable income and private consumption, resulting in heterogeneous policy impacts across household types. As the HBS does not provide individuallevel data, the Survey on Income and Living Conditions (SILC) is used to obtain the composition of household wage income regarding the types of labour (i.e. low-, medium- and high-skilled). Households determine their optimal level of composite (total) consumption by maximising their utilities subject to their budget constraint. The budget constraint of a RHG equates disposable income - the sum of wage income, dividend income, welfare transfers and pension income from the government, and net factor income from abroad - to the sum of total consumption expenditures and savings. The equilibrium between total income and expenditures must hold in every period of time. Household savings are determined as a residual, i.e. what households do not spend is saved.

2. Firms and Production: The production sector comprises 32 representative activities/firms which represent the different industries in the Irish economy. A list of the different sectors is presented in the Appendix. Each firm uses material inputs, energy inputs, labour and capital to produce a specific good. Firms are allowed to produce multiple product types, i.e. a firm can produce two or more products which are either secondary outputs of the primary production process or entirely different products. The I3E model models the interactions between different production sectors through the flow of inputs and outputs between sectors. The main data source to replicate intersectoral linkages in the Irish economy is the Supply and Use Tables (SUTs) provided by the CSO. The original SUTs provide information on which industry produces which products, the monetary value of production of each product, the cost of intermediate inputs, the value of gross value-added (payments to the factors of production), production taxes paid to the government, etc. The Labour Force Survey (LFS) is used to disaggregate the sectoral labour demand into types of labour. The bulk of activities determine the level of physical investment by maximising the value of the firm in an intertemporal manner. ${ }^{4}$

3. Commodities: There are 39 commodities or goods in the I3E model: two of them are entirely imported (crude oil and coal), 33 are both domestically produced and imported, and the supply of four commodities is entirely provided by domestic producers. The energy/carbon commodities included in I3E are peat, coal, natural gas, diesel, gasoline, kerosene, LPG, crude oil, fuel oil,

4 Having an intertemporal investment decision of firms allows the I3E model to explore economic dynamics in a more realistic framework. In the absence of such a feature, the model dynamics would only rely on the consumption smoothing of households, as households seek to achieve a stable level of utility over time. 
other petroleum products, and electricity. The total domestic demand for a commodity is equal to the sum of six items: intermediate input demand, household demand, government demand, investment demand, trade and transportation margin demand, and finally export demand. The SUTs provide data on the sources of supply (domestic production and import) and the sources of demand. From the supply side, domestic production and import are assumed to be imperfect substitutes for each other, i.e. a final consumer cannot substitute its domestic demand for import in a one-to-one manner. Each component of demand results from the optimisation of a user: intermediate input demand results from production cost minimisation by firms; household demand results from utility maximisation, government demand is a fixed share of the total government demand, investment demand is a fixed fraction of the total investment expenditures, trade and transportation margin demand is a fixed fraction of output, and export demand results from revenue maximisation by firms. For each commodity, an equilibrium condition is defined and associated with the price of the commodity, i.e. the commodity prices are endogenously solved in the model.

4. Labour Types: There are three types of labour in the I3E model: low-skilled, medium-skilled, and high-skilled. For the fixed supply of each type of labour, the labour market equilibrium conditions solve for the optimal wage rate. The SILC and LFS are utilised to get the compositions of wage income of households and labour demand of sectors, respectively.

5. Enterprises: The model includes an "enterprises" account, where a representative enterprise is assumed to be the owner of all firms. The account collects all gross sectoral profits and receives transfers from the government, which are fixed in nominal terms, and pays corporate tax to the government. The remaining amount is either saved by the enterprise account (fixed fraction of net-of-tax profit receipts) or paid to households as dividend payments.

6. Government: The I3E model has an explicit representation of the government sector. The government collects direct taxes on labour incomes and sectoral profits (corporate tax), indirect taxes on sales of commodities, the carbon tax on energy commodities, the export tax on exported electricity, production tax on production activities, and half of the cost of ETS due to the EU legislation. The carbon tax, which is exogenously determined by the government, is implemented as a fixed price of per-tonne equivalent of carbon and collected on the domestic consumption of energy-commodities. The government allocates its total revenues to the consumption of commodities, welfare transfers and pension payments to households (fixed in real terms - indexed to the average wage), transfers to enterprises (fixed in nominal terms), and interest payments over the outstanding foreign debt stock. The difference between total revenues and expenditures of the government is public saving which drives changes in the foreign debt stock, i.e. as public saving increases (decreases), the government debt stock becomes lower (higher).

7. Rest of the world: All monetary flows between the rest of the world and Ireland are traced within the RoW account. The sources of the foreign exchange supply are exports of commodities and 
the net factor income of households. The sources of foreign exchange demand are imports of commodities, the interest payments of the government over the outstanding foreign debt stock, and half of the cost of ETS due to the EU legislation. The difference between the totals of foreign exchange supply and demand is covered by foreign savings, i.e. the current account balance. The

foreign market closure rule implies that for the given level of foreign savings, the equilibrium in the rest of the world account is ensured by the exchange rate adjustment.

8. Emissions Trading Scheme (ETS): This is the primary environmental policy tool of the European Union (EU), where sectors covered by the system have to buy allowances if their emissions exceed their free allowances. ${ }^{5}$ The combustion-related emissions of the manufacturing sectors are partially and the emissions of energy production sectors are fully subject to the EU-ETS legislation. The I3E model has an explicit representation of the ETS: each activity takes into account its composition of energy demand, the activity emissions subject to the ETS, and free allowances to reduce its ETS emissions and thus the cost of the ETS. In this respect, each activity pays the same purchaser, i.e. retail, price to buy an energy commodity but the perceived cost of unit demand is a function of the activity's ETS coverage, free allowances, and the EU-ETS price which is an exogenous variable.

\subsection{Regional linking}

In this section, we outline the method used to calculate the county-level labour demand impacts based on the I3E's sectoral-level labour demand results. The I3E model results show the level of labour demand, per sector and skill-type, for each year under different experimental scenarios. The issue with the I3E results is that they represent sectoral labour demand change for the whole of Ireland and cannot, by themselves, inform us of any regional implications.

The county-level sectoral employment data is applied to supplement the I3E output to undertake a regional impact assessment. The CSO Business Demography dataset provides sectoral employment statistics for each of the 26 Irish counties. Importantly, the county-level breakdown is determined by the address at which an enterprise is registered. This is not necessarily the same as where the business conducts its day-to-day operations. It also means that, for an enterprise with multiple businesses located in different counties, all workers are counted as being registered in the single county from where the main office operates. Furthermore, the regional employment data is only available for 16 aggregated production sectors. The I3E model outputs, however, include a high level of detail. The production sector comprises 32 representative activities that represent the different industries. Using the NACE sector codes, the I3E sectors are mapped to the broader CSO sectors, and the requisite I3E labour demand results are aggregated to the broader CSO sectors using this mapping.

The regional employment data is applied to calculate county-level sectoral labour shares, by dividing the number of workers in sector $x$ in county $y$ by the total country-level number of workers in sector $x$, thus giving us the proportion of workers in each county for each production sector. We assume that these

\footnotetext{
5 For more information, see EPA (2018).
} 
county-level proportions are fixed over time. As the CSO Business Demography dataset does not include employment data for the agriculture and public administration sectors, additional datasets are utilised to calculate the county-level shares for these sectors. ${ }^{6}$

The relevant country-level I3E sectoral labour demand results are distributed across counties using the computed county-level shares to obtain the future regional impacts of a policy. For example, if the I3E model computed that 100,000 people are working in sector $x$ in 2030 in a specific policy scenario, those 100,000 workers are distributed to each county according to their calculated 2017 county proportions. The total county-level labour demand is then calculated, by aggregating the labour demand from each sector in a county, representing the county's projected labour force size under a policy. This figure is then compared to the business-as-usual $(\mathrm{BaU})$ scenario results, to provide overall county-level percentage changes in terms of labour demand.

\section{Scenario Design and Results}

This paper presents a policy scenario in which an increase in the carbon tax and a shift away from coal and peat usage in electricity production are jointly considered. A positive linear trend is assumed for the carbon tax: its level will increase $€ 6$ annually starting from 2020 and reach $€ 80$ in 2029 . Furthermore, the electricity production activity will gradually phase out coal and peat from the production process, and their usages will be terminated in 2026 and 2029, respectively. ${ }^{7}$ The results will be summarised compared to the $B a U$ scenario in which the abovementioned policy changes are assumed not to be realised. Along the path of $\mathrm{BaU}$, the total share of peat and coal in the total energy demand of the electricity production sector decreases from $23 \%$ in 2014 to $13.8 \%$ and $13.6 \%$ in 2020 and 2030, respectively. In the scenario analysis, on the other hand, the total share of peat and coal will be $9.7 \%$ in 2020 and zero in 2030, respectively. As the current version of the I3E model does not include renewable energy sources, it is assumed that the electricity production sector substitutes natural gas for peat and coal. ${ }^{8}$ The share of natural gas gradually increases from $34.4 \%$ in 2014 to $43.2 \%$ and $43.5 \%$ in 2020 and 2030 along $\mathrm{BaU}$. However, in the scenario analysis, its share will be $47.4 \%$ and $54.9 \%$ in 2020 and 2030, respectively.

6 In the case of the agriculture sector, two datasets are combined, one which contains updated 2017 employment data, but only at a regional (i.e. West, East, Midlands, etc.) level and one with county-level employment data for 2010. The 2010 county-level shares are used to disaggregate the 2017 regional labour data into the respective counties, to obtain the 2017 share parameters. For public administration, we use the "Population Aged 15 Years and Over in the Labour Force" CSO dataset.

7 Note that the Electricity Supply Board (ESB) has indicated that two of its peat plants in the Midlands will close at the end of 2020.

8 The absence of renewable energy sources has repercussions mainly on the emissions figures and the cost of electricity production. If there were renewables in the model, the electricity production sector would switch its demand from coal and peat either entirely to renewables or to a mix of renewables and natural gas. Since renewables are entirely indigenous production and their marginal cost is virtually zero, the cost of electricity production and thus the cost of production in other sectors will be lower, and the improvements in the trade balance and real GDP will be higher. Moreover, since natural gas is also a fossil fuel, increasing the share of renewables will have higher impacts on the emissions reduction process. The disaggregation of the electricity production sector into conventional and renewable-based sectors is in progress. 
In this section, we present the results concerning the county-level labour impacts. Firstly, we present the sectoral labour demand results from the I3E model. These results are then combined with county-level production statistics to determine county-level regional variation in labour demand impacts as a result of the tax. The results will concentrate on comparisons across production sectors.

It is important to note that the representation of the labour market in the I3E model is such that labour supply is given exogenously. Labour supply is assumed to grow at the pace of population growth. Hence, total labour demand will be equal in the $B a U$ case and in the case of policy changes considered in this report. The relative shares of labour demand in each production sector, however, will change due to policies. A repercussion of this structure on the sectoral composition of the labour demand is that if a sector is negatively affected by a shock, its employees will be displaced from this sector. Their wage rate will decline, and as there is no unemployment in the model yet, they will be employed in another sector which is affected either less adversely or positively.

It should also be noted that the following subsections will focus only on the results of the year of 2030, although the I3E model allows us to explore the joint impacts of policy changes for the entire model horizon, which is the year of 2055. The reason is that this paper focuses on the regional impacts, and the data used to disaggregate the macroeconomic aggregates to the regional figures is available only for 2017. In other words, as the regional analysis is static under the assumption that there will be no changes in the future regarding the shares of counties in total employment, providing the results for multiple periods would not add much to understand the regional impacts better.

\subsection{Macroeconomic Results}

The macroeconomic results are mainly driven by the phasing out of fossil fuels from the electricity production process due to the lower cost of electricity production, which eliminates the adverse economic impacts of increasing the carbon tax. The mechanism can be summarized as follows. The commodity coal is entirely imported, and the major portion of its total supply is demanded by the electricity production sector. As it is phased out from the production process, the import demand for coal shrinks by $96 \%$, compared to $B a U$. As the sector switches its demand from coal to natural gas, which is both produced domestically (63\% of the total domestic supply) and imported (37\% of the total domestic supply), demand for natural gas increases, which, in turn, invokes its domestic production as well as its import. However, since the international price of coal is lower than that of natural gas, there is an improvement in the trade balance. In addition, the cost of electricity production declines, which, in turn, lowers the cost of production and thus, domestic commodity prices. Lower domestic prices lead to lower inflation and lower the wage rate (by around 2.5\%). ${ }^{9}$ Lower commodity prices induce final demand of all agents in real terms, and the impact is the highest for the government $(2.2 \%)$, which is followed by the trade balance $(0.9 \%$ ) in 2030, compared to $\mathrm{BaU}$. As a result, real gross domestic product (GDP) will be $0.65 \%$ higher than its $B a U$ level in 2030. Without phasing out coal and peat, increasing the carbon tax would

9 The low-skilled workers are hit the hardest concerning the decline in the wage rate, but the differences across the labour types are negligible. 
lead to a $0.6 \%$ decline in real GDP, compared to $B a U$. Therefore, transitioning to a low-carbon electricity production leads to a one percentage point increase in the level of real GDP in 2030, compared to $B a U$, due to the decline in the cost of production.

\subsection{Sectoral Results}

Figure 1 presents the changes in labour demand in percentage terms compared to $B a U$ as a result of the climate policies for the aggregated production sectors. ${ }^{10}$ Impacts are largest in the mining sector, which faces an almost $8 \%$ decrease in labour demand, and the transportation sector with a $5 \%$ decrease. Several

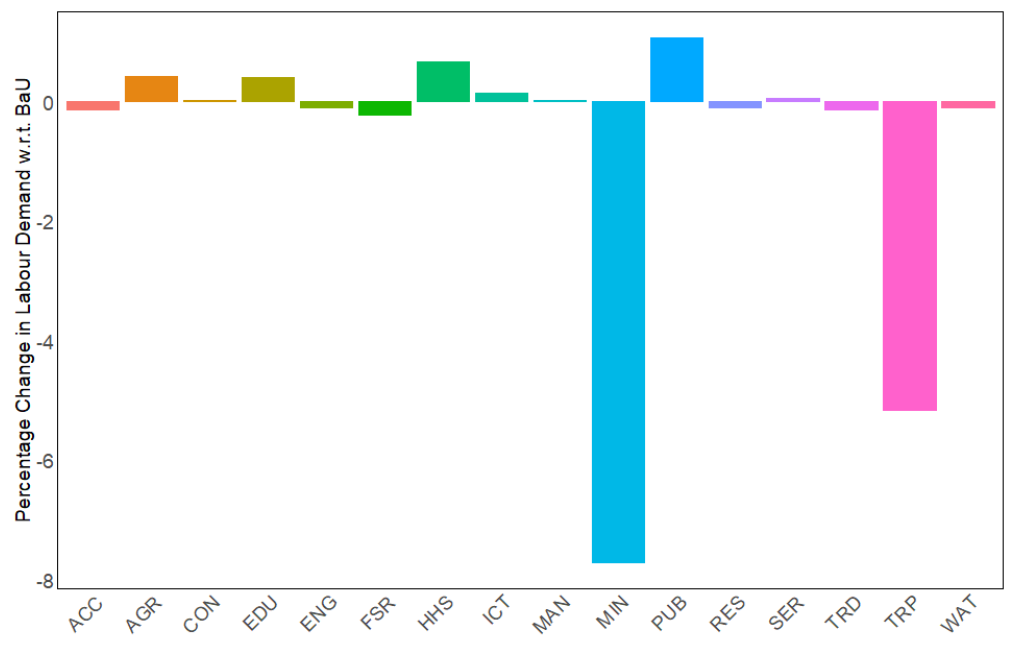

Figure 1: Labour demand in 2030 for aggregated production sectors, percentage change w.r.t. $B a U$

sectors face increases in labour demand such as agriculture, education, health, and public administration. As real government consumption increases, this leads to increases in labour demand in sectors with higher levels of government consumption for the commodities produced by sectors such as public administration, education, and health.

While Figure 1 depicts the sectoral-level labour demand changes, a number of these sectors are comprise multiple sectors. In order to illuminate the underlying results which drive the labour demand results for these composite sectors, the labour demand results for those disaggregated sectors are given below.

For the manufacturing sector, there is a variety of results, depicted in Figure 2. We see comparatively larger negative labour demand impacts for the petroleum and basic metal manufacturing sectors, with other smaller negative labour demand impacts for the pharmaceuticals, chemical and other manufacturing sectors. These negative labour demand impacts can be explained by the associated high levels of carbon used to maintain these industries. In contrast, there are larger positive labour demand impacts for the

\footnotetext{
10 Sectoral abbreviations are as follows: $A C C$ Accommodation and Hotel Services; AGR Agriculture; CON Construction; EDU Education sector; ENG Electricity and Natural Gas; FSR Financial Services; HHS Health sector; ICT Telecommunication services; MAN Manufacturing; MIN Mining; PUB Public sector; RES Real estate services; SER Other services; TRD Trade; $T R P$ Transportation; WAT Water and sewage. Full details are provided in the Appendix.
} 


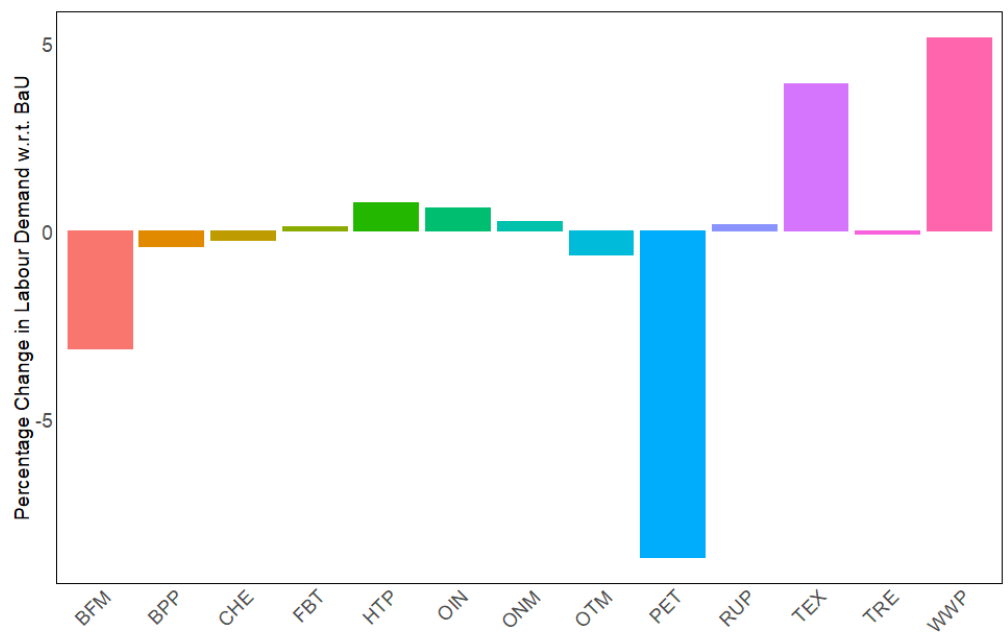

Figure 2: Labour demand in 2030 for disaggregated manufacturing sector, percentage change w.r.t. $B a U$

textiles and wood product sectors, and small labour demand increases in the high-technology and other industrial products sectors. Likewise, these impacts can be explained by the low carbon-intensive nature of these industries.

With regards to the mining sector, shown in red in Figure 3, it is unsurprising to see that the impacts in the aggregate mining sector are almost entirely driven by labour demand reductions in the peat sector. The results imply a more than $30 \%$ decrease in labour demand in the peat sector, compared to the $B a U$ scenario. As demand for peat in the economy declines (owing to the lack of availability of peat), the amount of labour required to meet that demand will also decline. One would expect such a large labour demand impact for the peat sector, given the plans to phase out the use of peat in the economy gradually starting from 2019. However, it should be noted that the share of the peat sector in economy-wide employment was $0.05 \%$ in 2014.

The electricity and natural gas sector demonstrates interesting and contrasting results, depicted in green in Figure 3. We see that the labour demand of the electricity sector goes down, due to the increase in electricity price. On the other hand, the gas sector's labour demand goes up, since natural gas replaces coal and peat in electricity generation and is, therefore, more demanded.

Lastly, for the transportation sector, shown in blue in Figure 3, there are associated labour demand decreases for all types of transportation. However, the most impacted sector is the air transportation sector, since this sector is the most carbon-intensive. The land and water transportation sectors also face labour demand decreases, being a little more than half as impacted as the air transportation sector.

It is also worth evaluating the relative importance of these impacted sectors by considering their respective sectoral value-added. As it transpires, the most affected sectors are comparatively small in terms of their value-added, namely the peat, electricity production, petroleum and multiple manufacturing sectors. The sectors with the largest value-added are comparatively less negatively or even positively 


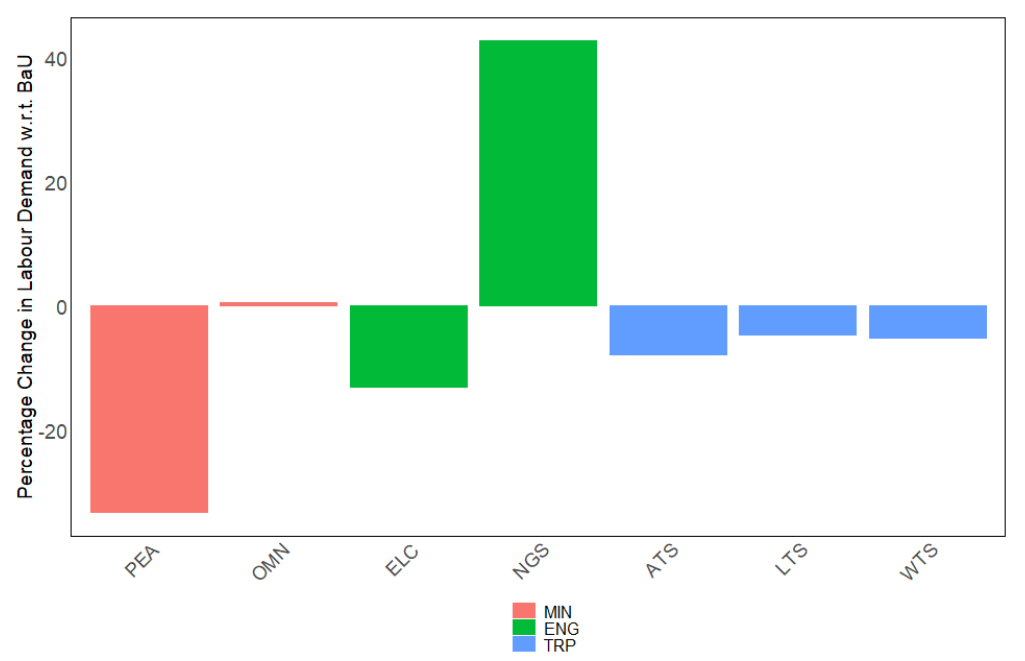

Figure 3: Labour demand in 2030 for disaggregated mining, electricity and natural gas, and transportation sectors, percentage change w.r.t. $\mathrm{BaU}$

affected. These include the services sectors, as well as education, health, and public administration.

Finally, how do these labour demand impacts affect on the worker? As described in section 2.1, the I3E model includes three labour skill types. For each labour type, supply and demand determine the equilibrium wage rate. As the most impacted sectors have relatively higher shares of medium-skilled (MSL) and particularly low-skilled labour (LSL), these labour types face larger wage decreases, though the differences are minimal. Note that the modelling framework applied does not include the explicit modelling of new technologies or industries and hence, only captures changes in labour demand in existing production sectors. It can well be argued that investments in new green technologies will create additional labour demand and push wages up.

\subsection{Regional Analysis}

Having presented the sectoral labour demand impacts from the increased carbon tax, we can now evaluate how these impacts will be spread across counties. We look firstly at the most impacted sectors, before presenting the overall results.

We highlighted that the production sectors which are most likely to be negatively impacted in terms of labour demand change are the mining and transportation sectors. To illustrate which counties may be most affected by employment changes in these sectors, we map the county-level employment shares, i.e. which share of the counties' labour force works in the sector, for each of these vulnerable sectors. These results are presented in Figures 4 and $5 .^{11}$

In the mining sector, we see that Roscommon and Carlow are likely to face the most significant negative labour demand impacts since a comparatively more substantial share of their workforce is employed

${ }^{11}$ County abbreviations are given as the nationally recognised vehicle registration plates. A full list of the abbreviations is given in the Appendix in Table 3. 
in these sectors. However, note the relatively small value of these shares; around $1 \%$ of the total workforce in these counties. Indeed, when looking again at the overall county-level labour demand impacts, we see that Roscommon has an overall positive labour demand impact, due to its share of positively impacted sectors, while Carlow sees only a minimal negative impact.

For the transportation sector, counties in the Midlands and the East are more impacted than those in the West and the South. The two most impacted counties are likely to be Monaghan and Dublin, for which the transportation sector accounts for around $6 \%$ of the total workforce. In the case of Dublin, this is due to its large share of air transportation employment in the country.

Figure 6 presents the projected 2030 labour demand impacts, compared to the $B a U$ scenario. These impacts reflect the total aggregated sectoral-level labour demand impacts. As can be seen on the map, there is a moderate level of county-level variation, with a mixture of positive and negative impacts. In terms of overall positive labour demand impacts, Western and Southern counties fair better, on average, than Eastern and Border counties. We project that Sligo will have the greatest positive overall labour demand impact at around $0.15 \%$. This can be explained by Sligo's very low share of workers in the most negatively impacted sectors, namely mining and transportation, and its higher share of workers in positively impacted sectors, such as the aforementioned government-based jobs. Despite its high national share of workers in the mining sector, Roscommon is projected to have one of the most significant overall positive labour demand increases, along with Tipperary and Galway. Similarly, the reasons for these counties' positive outlook is their relatively higher share of employees in the health services, education and public administration sectors.

Only a handful of counties are projected to have overall negative labour demand impacts. The two most impacted counties are Dublin and Westmeath, whose overall labour demand is projected to decrease by around $0.1 \%$ and $0.06 \%$ respectively. For the former, these results can be explained by Dublin's larger comparative share of workers in negatively impacted sectors like transportation and trade. In the case of Westmeath, the overall negative impact seems to mainly be derived from that county's very low share of workers in the health service (the most positively impacted) sector. Note, of course, that the large Dublin workforce will account for a more significant number of people than other counties, which is not reflected in the percentage-based analysis. Also, as our analysis is conducted based on the location of firms, the reduction in Dublin labour demand could have spillover impacts on surrounding commuter counties. 


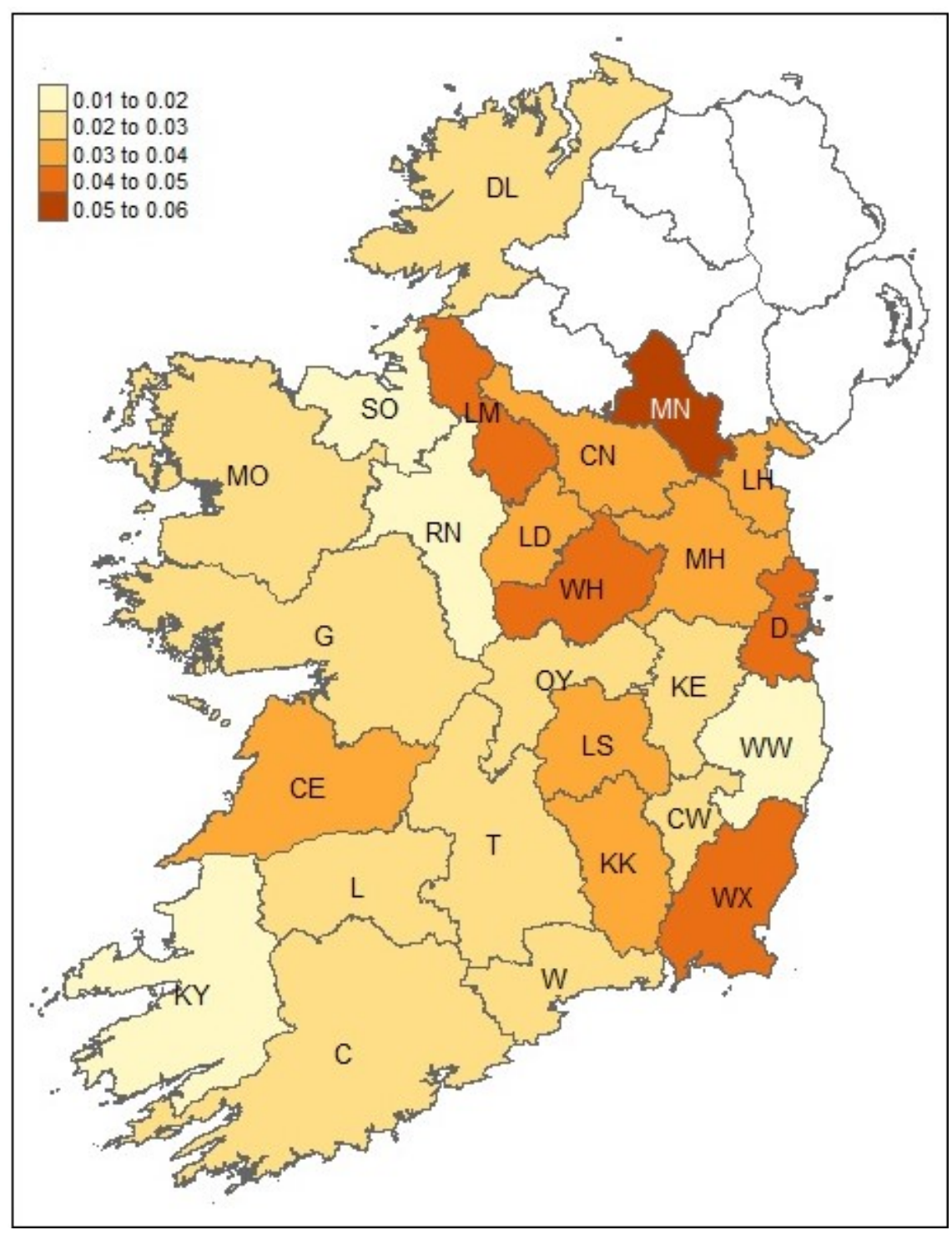

Figure 4: County-level shares of sectoral employment in total employment, transportation 


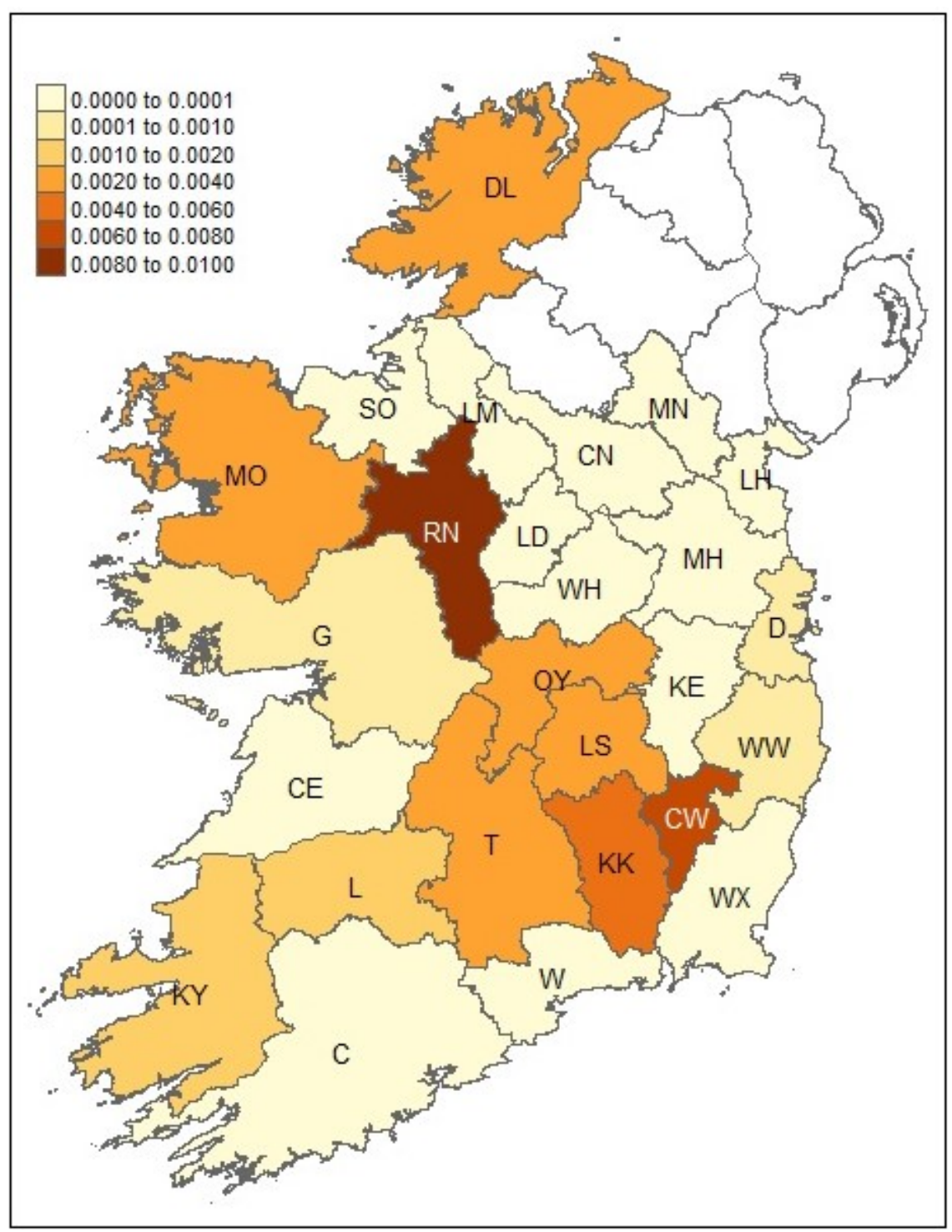

Figure 5: County-level shares of sectoral employment in total employment, mining 


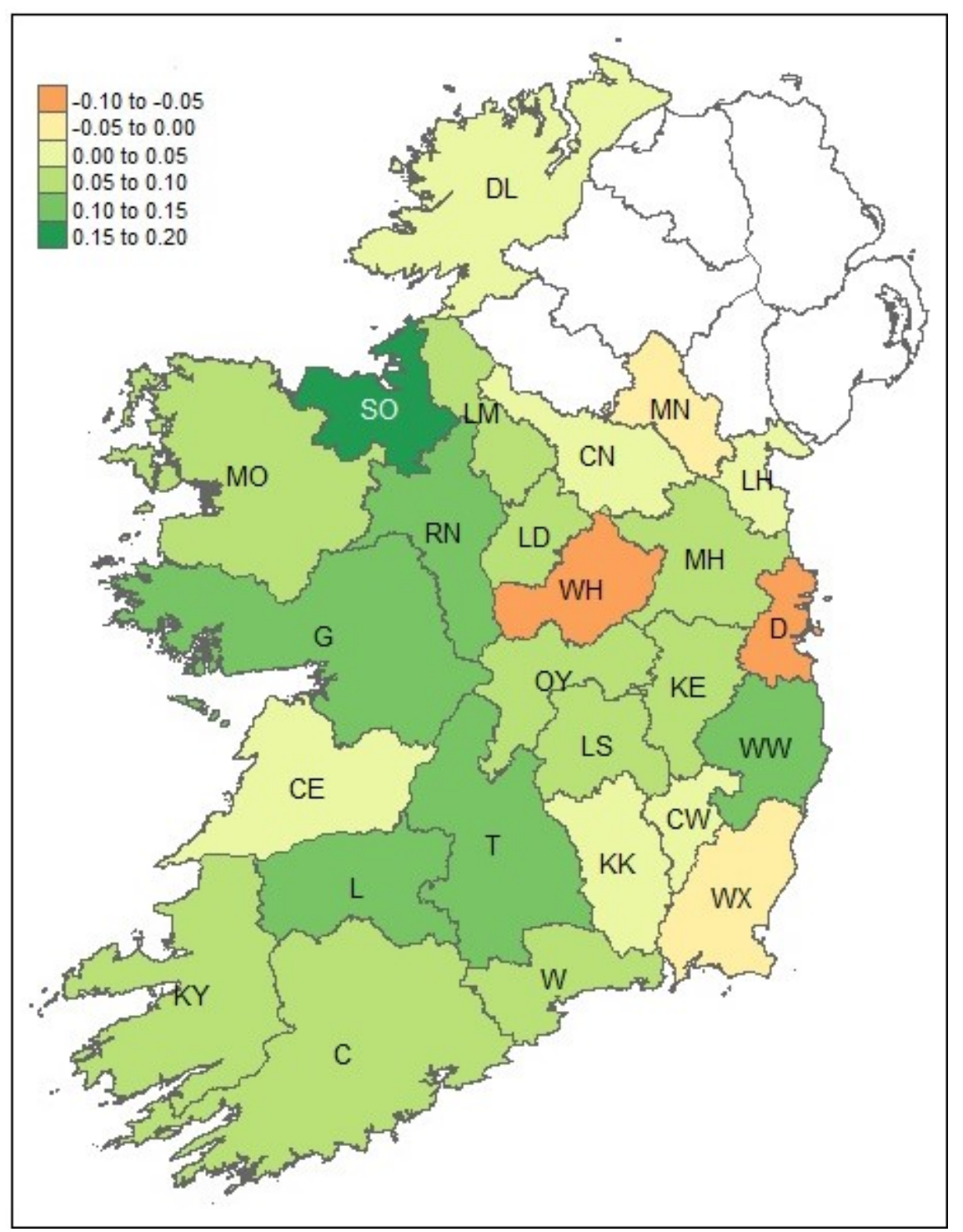

Figure 6: Labour demand in 2030 for aggregated production sectors, percentage change w.r.t. $\mathrm{BaU}$ 


\section{Conclusion}

In conclusion, we have outlined the projected sectoral labour demand impacts from an increase in the carbon tax, and a shift away from coal and peat use in electricity production. These sectoral impacts were then used to evaluate the likely regional impacts at an Irish county level, in order to accurately assess which counties may be disproportionately affected by the tax increase.

We established, as would be expected, that the mining and transportation sectors are most negatively affected, owing to their higher levels of carbon consumption. Meanwhile, government-based sectors like education, public administration and health services are likely to be the most positively affected in terms of labour demand. However, these most-impacted sectors have a comparatively lower value-added, and the sectors with the most value-added are mostly unaffected.

At a regional level, we find a moderate level of county variation in terms of overall labour demand impacts resulting from the environmental policies. Our paper projects that Sligo, Galway, Roscommon and other Western counties will have the most considerable positive labour demand impacts, owing to their higher share of workers employed in government-based jobs. Meanwhile, Westmeath and Dublin are likely to face the most substantial negative labour demand impacts, due to their comparatively larger shares of employees in the most negatively impacted sectors.

Within the most negatively impacted sectors, we find that Roscommon and Carlow are likely to face the most significant negative impacts in the mining sector, while in the transportation sector, Dublin and Monaghan are likely to be most negatively affected. These results are due to the size of the share of their workforce in these industries. It must be added, however, that these percentages are not large, and indeed Roscommon's negative labour demand impacts for mining are outweighed by positive labour demand impacts in other sectors.

Our study provide informative results for policy designers with regards to the carbon tax. In particular, it highlights the possible disproportionate impacts of the tax. A properly designed carbon tax policy, as well as the movement towards decarbonisation in these negatively affected sectors, may help to alleviate any possible negative labour demand impacts in the relevant sectors and counties and thus facilitate a "just transition" towards a non-carbon economy. 


\section{References}

Ciaschini, M., Pretaroli, R., Severini, F., \& Socci, C. (2012). Regional Double Dividend from Environmental Tax Reform: An Application for the Italian Economy. Research in Economics, 66, 273-283. doi: 10.1016/j.rie.2012.04.002

de Bruin, K. C., \& Yakut, A. M. (2019a). Construction of the Energy Social Accounting Matrix for Ireland (ESRI Survey and Statistical Report Series No. 78). Economic and Social Research Institute (ESRI). doi: 10.26504/sustat78

de Bruin, K. C., \& Yakut, A. M. (2019b). Technical Documentation of I3E Model, Version 2 (ESRI Survey and Statistical Report Series No. 77). Economic and Social Research Institute (ESRI). doi: $10.26504 /$ sustat77

Environmental Protection Agency (EPA). (2018). Who Needs a Permit? https://bit.1y/2XaOqoV.

FitzGerald, J., \& McCoy, D. (1992). The Economic Effects of Carbon Taxes. The Economic and Social Research Institute.

Government of Ireland. (2019). Climate Action Plan 2019 To Tackle Climate Breakdown. https:// bit. 1 y/206Uj2u.

Hassett, K. A., Mathur, A., \& Metcalf, G. E. (2009). The Incidence of a U.S. Carbon Tax: A Lifetime and Regional Analysis. The Energy Journal, 30, 155-177.

IILS. (2011). The Double Dividend and Environmental Tax Reforms in the European Union (EC-IILS Joint Discussion Paper No. 13). International Institute for Labour Studies.

Kato, M., Mittnik, S., Samaan, D., \& Semmler, W. (2013). Employment and Output Effects of Climate Policies (Tech. Rep. No. 12). Center for Quantitative Risk Analysis (CEQURA).

Vandyck, T., \& Regemorter, D. V. (2014). Distributional and Regional Economic Impact of Energy Taxes in Belgium. Energy Policy, 72, 190-203. doi: 10.1016/j.enpol.2014.04.004

Zhang, K., Xue, M.-M., Feng, K., \& Liang, Q.-M. (2019). The Economic Effects of Carbon Tax on China's Provinces. Journal of Policy Modeling, 41, 784-802. doi: 10.1016/j.jpolmod.2019.02.014 


\section{Appendix}

\section{Lists of Sectors, Commodities, and Counties}

Table 1: Sectors

\begin{tabular}{|c|c|c|c|c|}
\hline \multicolumn{2}{|r|}{ Activity } & NACE Codes & \multicolumn{2}{|c|}{ Aggregate Sector } \\
\hline ACC & Accommodation \& hotel services & $55-56,79$ & ACC & \\
\hline AGR & Agriculture & $1-3$ & AGR & \\
\hline $\mathrm{CON}$ & Construction & $41-43$ & $\mathrm{CON}$ & \\
\hline ELC & Electricity & & ENG & Electricity and \\
\hline NGS & Natural gas supply & & ENG & Natural Gas \\
\hline FSR & Financial services & $64-66,77$ & FSR & \\
\hline PUB & Public sector & 84 & PUB & \\
\hline TRD & Trade & $45-47$ & TRD & \\
\hline BFM & Basic metal manufacturing & $24-25$ & MAN & \\
\hline BPP & Basic pharmaceutical products & 21 & MAN & \\
\hline CHE & Chemicals and chemical products & 20 & MAN & \\
\hline FBT & Food, beverage and tobacco & $10-12$ & MAN & \\
\hline HTP & High-technology products & 26-28 & MAN & \\
\hline OIN & Other industrial products & $17,18,33$ & MAN & \\
\hline ONM & Other non-metallic products & 23 & MAN & Manufacturing \\
\hline OTM & Other manufacturing & $31-32$ & MAN & \\
\hline PET & Petroleum & & MAN & \\
\hline RUP & Rubber and plastic products & 22 & MAN & \\
\hline TEX & Textile & $13-15$ & MAN & \\
\hline TRE & Transportation equipment & $29-30$ & MAN & \\
\hline WWP & Wood and wood products & 16 & MAN & \\
\hline $\begin{array}{l}\text { OMN } \\
\text { PEA }\end{array}$ & $\begin{array}{l}\text { Other mining products } \\
\text { Peat }\end{array}$ & & $\begin{array}{l}\text { MIN } \\
\text { MIN }\end{array}$ & Mining \\
\hline ATS & Air transportation & 51 & TRP & \\
\hline LTS & Land transportation & 49 & TRP & Transportation \\
\hline WTS & Water transportation & 50 & TRP & \\
\hline WAT & Water and sewerage & $36,37-39$ & WAT & \\
\hline EDU & Education sector & 85 & EDU & \\
\hline HHS & Health sector & $86-88$ & HHS & \\
\hline RES & Real estate services & 68 & RES & \\
\hline SER & Other services & remaining* & SER & \\
\hline TEL & Telecommunication services & 61 & ICT & \\
\hline
\end{tabular}

*: It excludes NACE codes 5-9 (Mining, Quarrying and Extraction), 19 (Petroleum Products), and 35 (Electricity and Gas Supply).

Note: The activities without NACE codes are further disaggregated sectors. 
Table 2: Commodities

\begin{tabular}{|c|c|c|c|}
\hline AGR & Agriculture & BFM & Basic metal manufacturing \\
\hline PEA & Peat & HTP & High-technology products \\
\hline $\mathrm{COA}$ & Coal & TRE & Transportation equipment \\
\hline $\mathrm{CRO}^{*}$ & Crude oil & ELC & Electricity \\
\hline $\mathrm{OMN}^{*}$ & Other mining products & NGS & Natural gas supply \\
\hline FBT & Food, beverage and tobacco & WAT & Water and sewerage \\
\hline TEX & Textile & $\mathrm{CON}$ & Construction \\
\hline WWP & Wood and wood products & TRD & Trade \\
\hline OIN & Other industrial products & LTS & Land transportation \\
\hline GAL & Gasoline & WTS & Water transportation \\
\hline KRS & Kerosene & ATS & Air transportation \\
\hline FUO* & Fuel oil & $\mathrm{ACC}$ & Accommodation and hotel services \\
\hline LPG & Liquid petroleum gas & TEL & Telecommunication services \\
\hline DIE & Diesel & FSR & Financial services \\
\hline OPP & Other petroleum products & RES & Real estate services \\
\hline OTM & Other manufacturing & PUB & Public services \\
\hline $\mathrm{CHE}$ & Chemicals and chemical products & EDU & Education sector \\
\hline BPP & Basic pharmaceutical products & HHS & Health sector \\
\hline RUP & Rubber and plastic products & SER & Other services \\
\hline ONM & Other non-metallic products & & \\
\hline
\end{tabular}

*: Not subject to private consumption.

Table 3: County Abbreviations

\begin{tabular}{|c|c|c|c|}
\hline Abbreviation & County & Abbreviation & County \\
\hline C & Cork & LM & Leitrim \\
\hline CE & Clare & LS & Laois \\
\hline CN & Cavan & MH & Meath \\
\hline CW & Carlow & MN & Monaghan \\
\hline D & Dublin & MO & Mayo \\
\hline DL & Donegal & OY & Offaly \\
\hline G & Galway & RN & Roscommon \\
\hline KE & Kildare & SO & Sligo \\
\hline KK & Kilkenny & T & Tipperary \\
\hline KY & Kerry & W & Waterford \\
\hline L & Limerick & WH & Westmeath \\
\hline LD & Longford & WW & Wicklow \\
\hline LH & Louth & WX & Wexford \\
\hline
\end{tabular}


Whitaker Square,

Sir John Rogerson's Quay, Dublin 2

Telephone +35318632000

Email admin@esri.ie

Web www.esri.ie

Twitter @ESRIDublin

ISBN 978-0-7070-0514-0 